\title{
Pre-Service mathematics teachers' beliefs regarding topics of mathematics education
}

\author{
Katharina Manderfeld ${ }^{1}$ and Hans-Stefan Siller ${ }^{2}$ \\ ${ }^{1}$ University of Koblenz-Landau, Campus Koblenz, Germany \\ 2 Julius-Maximilians-University, Würzburg, Germany
}

Beliefs are known to influence learning processes and thus become relevant in the instruction of pre-service mathematics teachers with regard to the pedagogical content knowledge taught in courses of mathematics didactics at university. In exploring beliefs about mathematics didactics of pre-service teachers training for secondary school, 50 bachelor students (ca. 5th semester) responded to two openended tasks in which they were asked to express their understanding of mathematics didactics. With the help of qualitative content analysis, topics related to mathematics didactics as identified by the participants are categorized. The category system shows that beliefs of participants differ in some respects from what selected research associates with mathematics didactics. Also, technical aspects of lessons like designing lessons are frequently mentioned within the answers, whereas topics with regard to learners or curriculum are rarely addressed.

\author{
Keywords \\ mathematics didactics, \\ beliefs, \\ pre-service teachers, \\ inquiry, \\ qualitative content analysis \\ Correspondence \\ kmanderfeld@uni-koblenz.de \\ DOI \\ https://doi.org/10.31129/ \\ LUMAT.7.2.332
}

\section{Introduction}

Within this paper we will refer to 'mathematics didactics'. This term is used as translation for 'Mathematikdidaktik'. Biehler et al. (2002) "call the scientific discipline related to this research [of international organizations such as ICMI] and the research-based development work didactics of mathematics" (p.1). Further explanations of this concept can be found in the following.

During the teacher training period pre-service teachers are learners of subject specific as well as pedagogical knowledge. Pedagogical knowledge is taught and learned in educational science courses. Whereas content knowledge is conveyed in courses of mathematics; pedagogical content knowledge is the subject of instruction within the mathematics didactics courses. Those courses therefore pursue the aim of initiating learning processes of pre-service mathematics teachers regarding topics of mathematics didactics. According to constructivist theories about learning, Terhart (2003) defines learning as a process that "is never controlled in its course and result but always involves an individual - but in social contexts - constructing and reconstructing inner-worlds" (p. 32). As an individual process, learning is affected by inner conditions of the learner. During learning, different processes of cognitive, affective, and motivational nature interact (Op’t Eynde et al., 2006). As beliefs are a 
part of the affective domain of an individual (Goldin, 2002), they influence learning processes. "A person's beliefs [...] what (s)he finds interesting or important will, as such, have a strong influence on the situations (s)he will be sensitive to, and whether or not (s)he will engage in them" (Op’t Eynde et al., 2002, p. 15).

While other studies focus on beliefs about mathematics or its teaching and learning, the rational of this study is to research pre-service mathematics teachers' beliefs about mathematics didactics. Within studies regarding beliefs about mathematics and its teaching and learning, effects of beliefs towards the learning process have been approved (cf. Müller et al., 2008, p. 268). Theoretical and empirical considerations therefore lead to the assumption that beliefs pre-service mathematics teachers have about mathematics didactics, have an effect on their experience in learning pedagogical content knowledge at university. The objective of researching beliefs of pre-service mathematics teachers about mathematics didactics derives from this assumption. Bar-Tal (1990) mentions four areas of research regarding beliefs: It is possible to explore acquisition and change, structure, effects or contents of beliefs. This study focuses on contents of beliefs.

\section{Theoretical background}

\subsection{Dealing with beliefs}

With regard to constructivist theories about learning, beliefs can be seen as reflections of the individually constructed reality of each learner. They can be defined as being "mental constructs that represent the codifications of people's experiences and understandings" (Schoenfeld, 1998, p. 19). Rokeach (1975) characterizes each belief as having three components: a cognitive, an affective and a behavioural component. In this paper, we will focus on cognitive components of beliefs about mathematics didactics. Regarding this component, Rokeach (1975) claims that beliefs represent a person's knowledge. Accordingly, beliefs can be labeled as "subjective (personal) knowledge" (Furinghetti \& Pehkonen, 2002, p. 43) or "internal knowledge" (Lester, 2002, p. 351). Although concentrating on cognitive components, each time a participant makes a choice about mentioning a content of mathematics didactics his or her own evaluation on the acceptability of this content plays a role. Therefor those beliefs also contain an affective dimension (Pehkonen, 1994). 
Within the definition of Schoenfeld beliefs are mentioned to be codifications of people's experiences. Pre-service teachers made individual experiences during their time as students, during their teacher education or during their private life, for example when giving extra lessons to students. Those experiences form and influence their beliefs. According to Blömeke's (2003) review of literature, pre-service teachers seem to know what lessons should look like and thus intend to learn just a repertoire of methods when entering teacher training. Within their review of literature about conceptual change in teachers' conceptions of learning, motivation and instruction, Pintrich and Patrick (2001) state pre-service teachers appearing to pay less attention to their role in facilitating learning and understanding students.

\subsection{Mathematics didactics as object of beliefs}

As beliefs can be seen as part of the "internal knowledge" (Lester, 2002, p. 351), there also exists "external knowledge" (Lester, 2002, p. 351). The latter can be defined as "knowledge resulting from the consensus of some community of practice" (Lester, 2002, p. 351). In order to compare the answers of the participants with something that could be seen as external knowledge, we will have a closer look at selected works of researchers (see Table 1). These works deal with mathematics didactics as a scientific discipline or pedagogical content knowledge as the knowledge that is dealt within this discipline.

Table 1. Dimensions of pedagogical content knowledge (Ball et al., 2008 \& Kunter et al., 2013) and areas of research in mathematics didactics (Vollstedt et al., 2015).

\begin{tabular}{|c|c|c|}
\hline Ball et al. (2008) & Kunter et al. (2013) & Vollsted et al. (2015) \\
\hline $\begin{array}{l}\text { Knowledge of content and } \\
\text { curriculum }\end{array}$ & $\begin{array}{l}\text { Knowledge of mathematical } \\
\text { tasks }\end{array}$ & Contents of mathematics \\
\hline $\begin{array}{l}\text { Knowledge of content and } \\
\text { teaching }(\mathrm{KCT})\end{array}$ & Explanatory knowledge & $\begin{array}{l}\text { Learning and teaching } \\
\text { environments such as lessons }\end{array}$ \\
\hline \multirow{2}{*}{$\begin{array}{l}\text { Knowledge of content and } \\
\text { students } \\
\text { (KCS) }\end{array}$} & $\begin{array}{l}\text { Knowledge of students' } \\
\text { mathematical thinking }\end{array}$ & Learner \\
\hline & & Teacher \\
\hline
\end{tabular}

Within their scientific work Ball et al. (2008) as well as Kunter et al. (2013) created models, in which pedagogical content knowledge is differentiated. Exploring the knowledge that is needed to fulfill the tasks of teaching, Ball et al. (2008) created a 
model of 'mathematical knowledge for teaching'. Within their model, they distinguish different parts of pedagogical content knowledge (see Table 1). One dimension of pedagogical content knowledge that Ball et al. (2008) distinguish in their model is 'Knowledge of content and curriculum'. They claim this knowledge to be part of pedagogical content knowledge, but it is not considered in their further research. Furthermore, pedagogical content knowledge as well as mathematics didactics as a scientific discipline are in context with what happens within a mathematics classroom. Accordingly, Ball et al. (2008) frame one facet of this knowledge by 'knowledge of content and teaching' (KCT). Within other publications this knowledge is also called "mathematical knowledge of the design of instruction" (Hill et al., 2007, p. 132). It is for example about finding examples for the access to a new topic, evaluating different forms of representations and using methods (Ball et al., 2008). Besides dealing with mathematical contents and designs of lessons, pedagogical content knowledge and research with a special view to students is needed. Therefore, 'Knowledge of content and students' (KCS) contains knowledge about common student errors, students' understanding of a content, their developmental sequences and their common computational strategies (Hill et al., 2008).

The research program "Professional Competence of Teachers, Cognitively Activating Instruction, and the Development of Students' Mathematical Literacy (COACTIV)" (Kunter et al., 2013, p.1) aims at identifying the individual characteristics that teachers need to solve their professional tasks successfully (Kunter et al., 2013). Professionalism is seen here as an interaction of specific, experience-based, declarative and procedural knowledge which form a competence in the narrow sense (Kunter et al., 2013). Within their model they distinguish different aspects of professional competence. Besides motivational-affective components, professional knowledge as one component is separated into different domains of knowledge. One domain is framed by pedagogical content knowledge, which is further separated into different facets (see Table 1). The model of the COACTIV-program does not mention a special facet of knowledge concerning the curriculum, but they claim 'knowledge of mathematical tasks' to be one part of pedagogical content knowledge. It is further defined as "knowledge of the didactic and diagnostic potential of tasks, their cognitive demands and the prior knowledge they implicitly require, their effective orchestration in the classroom, and the long-term sequencing of learning content in the curriculum" (Kunter et al., 2011, p. 33). "Knowledge of explanations and multiple representations" (Kunter et al., 2013, p. 33) or 'explanatory knowledge' is in a similar way paid 
attention to within the 'knowledge of content and teaching' (KCT) by Ball et al. (2008). Misconceptions, typical errors and strategies, ways of assessing students' knowledge and their process of learning are also mentioned as a part of pedagogical content knowledge within the facet of 'Knowledge of students' mathematical thinking'.

Finally, we refer to an article by Vollstedt et al. (2015) that describes research objects and objectives of mathematics didactics as a scientific discipline by representing four areas of research (see Table 1). Research regarding mathematical tasks or the curriculum is seen by Vollstedt et al. (2015) as part of an area of mathematics didactics that deals with the role of the contents of mathematics. Choosing, legitimizing, and preparing mathematical contents for schooling are research objectives regarding this area (Vollstedt et al., 2015). According to Vollstedt et al. (2015) mathematics didactics as a scientific discipline further needs to research mathematical classroom-settings and learning materials, for which explanations and representations are used. Furthermore, the structure and development of mathematical competences of students and their conceptions need to be understood (Vollstedt et al. 2015). Therefore, learners frame objects of research within mathematics didactics but teachers also provide this. Research within mathematics didactics also deals with exploring the personalities of teachers, their professional competence, and their professional development (Vollstedt et al., 2015). The last area comprising teachers only becomes a relevant area when dealing with mathematics didactics as a scientific discipline. Corresponding aspects are not mentioned within the models of pedagogical content knowledge by Ball et al. (2008) or the COACTIVprogram (Kunter et al., 2013).

\section{Research question}

Learning contents corresponding to pedagogical content knowledge, however, depends on beliefs that pre-service teachers have towards the subject of mathematics didactics. Accordingly, research is needed to better understand the beliefs held by preservice mathematics teachers with regard to mathematics didactics.

With this study, we want to explore contents of beliefs pre-service mathematics teachers have by answering the following research question: "Which content-related beliefs regarding topics of mathematics didactics are mentioned by participants when expressing their understanding of mathematics didactics?” 


\section{Methods and Sample}

Having the aim in mind to explore the contents of beliefs, the pre-service mathematics teachers were asked about their understanding of mathematics didactics within the study. Answers can be seen as written representations which provide insights into the subjective knowledge of mathematics didactics. Those answers were analyzed by having a closer look at topics of mathematics didactics that are mentioned by the preservice mathematics teachers. According to Schoenfeld's definition, the mentioned topics represent the codifications of people's experiences and understandings. They are part of the mental image and subjective knowledge the pre-service teachers have about mathematics didactics and thus are part of their beliefs. As beliefs in terms of subjective knowledge are held individually and thus subjective, they "can never be judged to be correct or incorrect" (Op't Eynde et al., 2002, p. 24). Instead, the answers are compared to selected works by researchers, who tried to examine what pedagogical content knowledge and mathematics didactics are.

\subsection{Participants, sampling and data collection}

Teacher training in Germany is tri-parted in stages of learning: Bachelor of Education, Master of Education and subsequent in-school preparatory service. This research was undertaken during the Bachelor period of studies which generally lasts approximately 3 years, each year consisting of a winter and summer semester. Within the Bachelor program pre-service teachers take courses in the two subjects' areas they will teach, as well as educational science courses, and must also complete three internships. Those pre-service teachers who chose mathematics as one of their subjects have to take courses and pass exams in mathematics as well as in didactics of mathematics. When examining beliefs held by pre-service teachers in Germany with regard to didactics of mathematics, one aspect should be considered. The word 'Mathematikdidaktik' (didactics of mathematics) in Germany is unknown for most of the pre-service teachers at the beginning of their teacher training. This means that our research intentionally excluded first semester students, assuming that pre-service teachers in subsequent semesters already have experienced the word 'Mathematikdidaktik' and have an idea about its meaning. Due to the fact that there is not much knowledge about the beliefs of preservice teachers regarding mathematics didactics, an exploratory study is realized that aims to explore these beliefs. 
In order to answer the research question, 50 pre-service mathematics teachers studying at a German university participated in an inquiry (age: $\mathrm{M}=23.02, \mathrm{SD}=3.15$; semester: $\mathrm{M}=5.62, \mathrm{SD}=2.84$; sex: female $=62,5 \%$, male $=37,5 \%)$. They were at least in the fourth semester and all had previously passed one exam in mathematics didactics. Within the corresponding lecture of this exam, the topics taught included topics regarding mathematics lessons (such as use of media), topics regarding learners (such as specific learning theories) and topics referring to mathematical contents (such as general objectives of mathematics education). All of the pre-service teachers who took part want to become teachers in secondary schools and have completed one threeweek internship.

The inquiry was made at a preparation meeting during the semester break. We wanted to ensure that the participants were not working on a topic of mathematics didactics at that moment because this might have influenced their answers. The researcher, who is not and has never been an instructor for the participants, implemented the inquiry. The participants of the preparation meeting were free to take part, but there no one refused the participation. Furthermore, the inquiry was realized as a paper-pencil-questionnaire and the answers were anonymous. Within the framework of the inquiry, the participants had to answer questions regarding sociodemographic information (sex, age etc.) and two open-ended tasks. By answering the first task (Please describe what you think mathematics didactics is.), the participants were asked to formulate their personal definition of mathematics didactics. The second task (What kind of mathematical-didactical requirements must be fulfilled by a mathematics teacher?) focused on mathematics didactics as a field of competences in the context of mathematics lessons. The inquiry was placed at the very beginning of the preparation meeting and the participants had as much time to answer as they needed.

\subsection{Data Analysis}

The answers were analyzed using qualitative content analysis. Regarding the research question, it was designed to elicit beliefs regarding topics associated with mathematics didactics as described by the participants. For this reason, a thematic qualitative text analysis (Kuckartz, 2014a) was chosen.

We decided to form categories in a deductive-inductive way. Therefore, we used the four areas of topics derived from Vollstedt et al. (2015), mathematical content, 
lessons, teacher, learner, and used them as our main categories. As can be seen in Table 1, it is possible to structure the facets of pedagogical content knowledge and research objectives of mathematics didactics as a scientific discipline by using these four areas. The topics that were mentioned by the participants within their expression of beliefs about mathematics didactics were matched to one of these main categories. Subcategories were formed inductively.

Giving insight into the process of coding, Table 2 and Table 3 show two translated answers chosen as examples of codings in different categories.

Table 2. Translated answer to the task: "Please describe what you think mathematics didactics is."

\begin{tabular}{ll}
\hline Answer & Codings \\
\hline $\begin{array}{l}\text { With mathematics didactics, I understand the doctrine of how to transfer } \\
\text { certain contents to students. }\end{array}$ & transfer of knowledge \\
Therefore, content knowledge is needed. & professional knowledge \\
$\begin{array}{l}\text { Teachers must know how to realize problems of students and how to solve } \\
\text { them effectively. }\end{array}$ & diagnostic work \\
$\begin{array}{l}\text { Furthermore, a teacher should use different solution paths for a task } \\
\text { and different methods for designing lessons. }\end{array}$ & preparation of contents \\
\hline
\end{tabular}

Table 3. Translated answer to the task: "What kind of mathematical-didactical requirements must be fulfilled by a mathematics teacher?"

\begin{tabular}{ll}
\hline Answer & Codings \\
\hline $\begin{array}{l}\text { Orientation towards the learners' individuality } \\
\text { Being able to reduce mathematical contents in a way that preferably all } \\
\text { students can understand them choosing appropriate tasks }\end{array}$ & $\begin{array}{l}\text { learner } \\
\text { preparation of contents } \\
\text { preparation of contents } \\
\text { Choosing appropriate contents }\end{array}$ \\
$\begin{array}{l}\text { Considering aspects regarding the psychology of learning, like } \\
\text { preconceptions of the students }\end{array}$ & learner \\
Knowing a variety of teaching techniques & \\
Choosing appropriate methods & designs of lessons \\
Using different methods & designs of lessons \\
\hline
\end{tabular}

Qualitative content analysis is a systematic proceeding governed by rules and oriented towards quality criteria of validity and reliability (Schreier, 2014). In terms of validity, it is a requirement to create a category system in such a way that it is able to capture essential aspects of meaning. Schreier (2014) claims that at least one 
category needs to be formed inductively. In line with that claim, all subcategories within this research were formed inductively. Regarding reliability, a text apprehension needs to be as intersubjective and consensual as possible (Schreier, 2014). Therefore, each participant's answer was coded by three different persons (researcher and two student assistants, who were trained for this task) followed by a discussion of each coding. If there was a disagreement, it was discussed from different points of view and then a decision was made, and the guideline of coding was adjusted. This approach is called "consensual coding” (Kuckartz, 2014, p. 211).

The study follows a mixed-methods-design. As also frequencies of codings will be mentioned, qualitative findings will be quantified. This transformation of data reasons a transfer design of the study (Kuckartz, 2014b).

\section{Findings}

According to the research question, we will first consider the category system (see Fig. 1). As it was mentioned in the methods section, all topics were subordinated to one of the four main categories: mathematical content, lesson, teacher or learner.

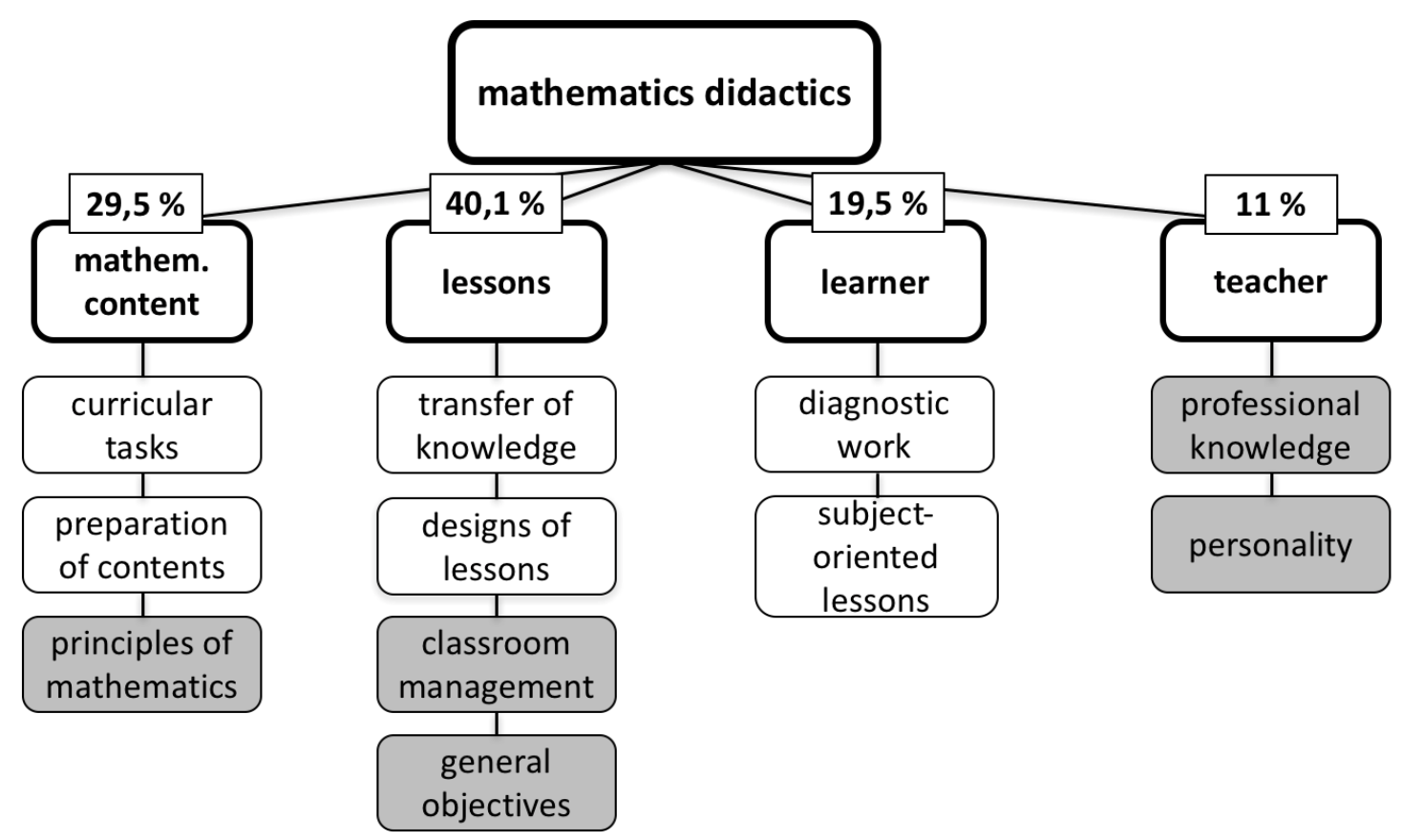

Figure 1. Category system and distribution of codings regarding the main categories.

As seen in Figure 1, some subcategories are marked in grey. This is because they do not fit with what was derived as being topics of mathematics didactics in the 
theoretical background. In terms of the first main category, 'mathematical content', in line with 'knowledge of content and curriculum' (Ball et al. 2008) 'curricular tasks' were mentioned. One participant, for example, stated: 'A mathematics teacher should be aware of principles of mathematics didactics that are needed to understand the curriculum'. As well 'preparation of contents' is mentioned, in which knowledge of mathematical tasks (Kunter et al., 2013), for example, is needed. An exemplary coding for this category is the following: 'Mathematics didactics is about illustrating mathematics for students in different ways'. But there were four participants explaining their understanding of mathematics didactics by defining it as 'principles of mathematics' (e.g. 'By mathematics didactics I understand a science that represents principles of mathematics'; 'In mathematics didactics important terms of mathematics are learned.'). This understanding differs from what was defined as being topics of mathematics didactics. Principles of mathematics are seen as being part of content knowledge (Kunter et al., 2013). 29.5\% of all codings are matched to the category 'mathematical content'. Furthermore, nearly every answer of a participant (46 of 50) has at least one coding within this main category. A subcategory frequently used is 'preparation of contents', coded within 39 answers. In contrast, the subcategory of 'curriculum' was used within 18 different answers.

The second main category deals primarily with technical aspects of 'lessons', such as the 'knowledge of content and teaching' (Ball et al., 2008) and 'explanatory knowledge' (Kunter et al., 2013). Again, three sub-categories were built, one of which is about the central idea of 'transferring knowledge' in mathematics lessons ('Mathematics didactics should explain how to transfer content knowledge in the best way.'). Secondly, one subcategory collects all passages that deal with 'designs of lessons', such as using methods or materials, time management or the structure of lessons. Accordingly, one participant wrote: 'Mathematics didactics offers tools which help teachers to design their lessons.' Regarding the subcategories 'classroom management' (e.g. 'I think within mathematics didactics we will be taught about disturbances during lessons and how to solve them.') and 'general objectives', (e.g. 'Mathematics didactics is not only about teaching mathematical contents, but also about promoting aspects like communication'), topics were mentioned that are not specific to mathematics classes. Because of not being specific to mathematics teaching, classroom management, for example, is seen as part of pedagogical and psychological knowledge in the framework of the COACTIV-program (Kunter et al., 2013). Concerning the distribution of codings (see Figure 1), more than one third of 
them are found in the category 'lesson' (40.1\%). It can be stated that the answers of each participant have at minimum one coding within the main category 'lesson'. By including the subcategories, it can be said that especially 'designs of lessons' and 'transfer of knowledge' were frequently coded (at minimum one coding within 43 or 45 answers). Non-mathematics related issues such as classroom management and general objectives of education have in comparison been rarely coded (within three and five answers).

The main category dealing with the 'learner', comprises all topics mentioned by the participants that have to do with student individuality. Based on this, the lessons and actions of a teacher are adapted to the special audience they face within a classroom. 9.5\% of all codings were matched to this main category. There were 10 participants writing about mathematics didactics without mentioning anything that could be matched to the category of learner (mentioned by 40 of 50 participants). One sub-category is framed by the 'diagnostic work' of a teacher which includes understanding, assessing, and reacting to students' learning processes, like it is mentioned in the following: 'Mathematical-didactical requirements of a teacher are about realizing talents and weaknesses of students and dealing with them'). Another subcategory is framed by passages regarding a 'subject-oriented lesson' (e.g. 'Mathematical-didactical requirements are about teaching content knowledge in a way, that individual needs of each student are paid attention to.'). Half of the participants did not mention anything that could be coded within the subcategory of 'subject-oriented lessons' (mentioned by 25 of 50 participants) while 20 did not connect mathematics didactics with topics deriving from 'diagnostic work' of a teacher (mentioned by 30 of 50 participants).

While the other main categories, including topics that frame objects and objectives of mathematics didactics as a scientific discipline, are connected to competences that are claimed in the context of mathematics lessons or/and are learning contents within teacher training, the implementations of the category 'teacher' differ. The participants expressed neither research areas of mathematics didactics nor competences or learning contents regarding pedagogical content knowledge but rather aspects of 'personality' and 'professional knowledge', especially content knowledge, as mathematics didactical qualities a (mathematics) teacher needs to have in their opinion (e.g. 'A teacher should have a strong personality.'; 'A teacher should have a high level of content knowledge.'). Those topics differ from the topics of mathematics didactics derived by selected research. Regarding mathematics didactics as a scientific 
discipline, researching the personality of mathematics teachers is mentioned, but having a certain kind of personality is not connected to mathematics didactics or pedagogical content knowledge within the literature. $11 \%$ of all codings are matched to this main category. Sub-categories such as 'professional knowledge' and 'personality' of a teacher are coded within 25 and 20 answers.

\subsection{Different focuses}

Concerning each individual answer, 22 participants focused on topics that were coded within the category of 'lessons'. 'Focused' means in this case that most of the codings in the answers of a participant are made within this category. A focus is only mentioned when one main category has at minimum two more codings than all the others (Mcodings=11,84). In contrast to the use of this category, the others are underrepresented (rarely or not used) in the answers of those participants. Similarly, there were 13 participants focusing primarily on 'mathematical contents' when expressing their understanding of mathematics didactics. Another two participants focused on 'learner', while 13 participants used two or more main categories similarly frequently.

\section{Discussion}

Regarding the research question, we were able to see that especially the contents of mathematics lessons were frequently mentioned within the answers of the participating pre-service mathematics teachers. This shows that those topics are strongly connected to the mental image and subjective knowledge (beliefs) pre-service teachers have towards mathematics didactics. Blömeke (2003) mentions pre-service teachers intend to learn just a repertoire of methods when entering teacher training. This might be a reason why the participants in this study frequently stated topics of mathematics didactics that can be coded in the main category of 'lessons' and also nearly half of the participants (22) focused on those topics when describing their understanding of mathematics didactics. In contrast, curricular topics and those dealing with learners seem to be underrepresented within the beliefs of the participants regarding topics of mathematics didactics. Pintrich and Patrick (2001) report similar findings regarding the underestimation of topics related to learning processes of students. The results also show that some topics the participants mentioned cannot be matched to mathematics didactics from the point of view of 
research that was derived by selected research works. Mathematics didactics being a discipline where principles of mathematics, general pedagogical or personality issues are learned neither fit into the models of Ball et al. (2008) or Kunter et al. (2013) nor are in line with the remarks by Vollstedt et al. (2015) as explained in the findingssection.

It should be noted that 7 of 584 codings in total represent topics that were learned during the first lecture of mathematics didactics (e.g. being aware of the different phases of a modelling process), thus possibly influencing their thoughts, in addition to the general topics of mathematics didactics already known.

Furthermore, we found that participants focused on different areas of topics when talking about mathematics didactics. This might be a sign of different, more general beliefs regarding topics of mathematics didactics. In the next step, selected participants are interviewed to enable a deeper view into the beliefs hold about mathematics didactics as dealing with the topics connected to this discipline is only to be seen a superficial first step to approach to these beliefs.

\section{Acknowledgements}

The MoSAiK project (modular inclusion of practical school experience as a starting point for the individual development of competences) is funded with support from the German Federal Ministry of Education and Research within the framework of the National Program to Improve the Quality of Teacher Training (Kauertz \& Siller, 2016).

\section{References}

Ball, D., Thames, M., \& Phelps, G. (2008). Content Knowledge for Teaching. What Makes It Special? Journal of Teacher Education, 59(5), 389-407.

https://doi.org/10.1177/0022487108324554

Bar-Tal, D. (1990). Group Beliefs. A Conception for Analyzing Group Structure, Processes, and Behavior (1 edition). New York: Springer. http://dx.doi.org/10.1037/1089-2699.11.3.187

Biehler, R., Scholz, R. W., Sträßer, R., \& Winkelmann, B. (2002). Didactics of mathematics as a scientific discipline. Dordrecht, The Netherlands: Kluwer. http://dx.doi.org/10.1007/0306-47204-X

Blömeke, S. (2003). Lehrerausbildung - Lehrerhandeln - Schülerleistungen. https://edoc.huberlin.de/bitstream/handle/18452/2354/bloemeke.pdf?sequence=1

Furinghetti, F., \& Pehkonen, E. (2002). Rethinking Characterizations of Beliefs. In G. C. Leder, E. Pehkonen, \& G. Törner (Eds.), Beliefs: a hidden variable in mathematics education? (pp. 39 - 58). Dordrecht, The Netherlands: Kluwer. https://doi.org/10.1007/0-306-47958-3 
Goldin, G. A. (2002). Affect, Meta-Affect, and Mathematical Belief Structures. In G. C. Leder, E. Pehkonen, \& G. Törner (Eds.), Beliefs: a hidden variable in mathematics didactics? (pp. 59

-72). Dordrecht, The Netherlands: Kluwer. https://doi.org/10.1007/0-306-47958-3

Hill, H. C., Ball, D. L., \& Schilling, S. G. (2008). Unpacking Pedagogical Content Knowledge: Conceptualizing and Measuring Teachers' Topic-Specific Knowledge of Students. Journal for Research in Mathematics Education, 39(4), 372-400.

Hill, H. C., Lewis, J., Sleep, L., Lewis, J. M., \& Ball, D. L. (2007). Assessing Teachers' Mathematical Knowledge: What Knowledge Matters and What Evidence Counts? In F. K. J. Lester (Eds.), Handbook for Research on Mathematics Education (pp. 111-155). Charlotte, NC: Information Age. https://doi.org/10.1177/0022487108324554

Kauertz, A., \& Siller, H.-S. (2016). Modulare Schulpraxiseinbindung als Ausgangspunkt zur individuellen Kompetenzentwicklung. https://mosaik.uni-koblenz-landau.de

Kuckartz, U. (2014a). Qualitative Text Analysis. A Guide to Methods, Practice \& Using Software. London, UK: SAGE. http://dx.doi.org/10.4135/9781446288719

Kuckartz, U. (2014b). Mixed Methods: Methodologie, Forschungsdesigns und Analyseverfahren. Wiesbaden, Germany: Springer.

Kunter, M., Baumert, J., Blum, W., Klusmann, U., Krauss S., \& Neubrand, M. (2013). Cognitive Activation in the Mathematics Classroom and Professional Competence of Teachers. Results from the COACTIV Project. New York, NY: Springer US.

https://doi.org/10.1007/978-1-4614-5149-5

Lester, F. K. J. (2002). Implications of Research on Students' Beliefs for Classroom Pracice. In G. C. Leder, E. Pehkonen, \& G. Törner (Eds.), Beliefs: a hidden variable in math-ematics education? (pp. 345-354). Dordrecht, The Netherlands: Kluwer. https://doi.org/10.1007/0-306-47958-3

Müller, C., Felbrich, A., \& Blömeke, S. (2008). Überzeugungen zum Lehren und Lernen von Mathematik. In S. Blömeke, G. Kaiser, \& R. Lehmann (Eds.), Professionelle Kompetenz angehender Lehrerinnen und Lehrer: Wissen, Überzeugungen und Lerngelegen-heiten deutscher Mathematikstudierender und -referendare. Erste Ergebnisse zur Wirksamkeit der Lehrerausbildung (pp. 247-276). Münster, Germany: Waxmann.

Op’t Eynde, P., De Corte, E., \& Verschaffel, L. (2002). Framing Students' Mathematics-Related Beliefs. A Quest for Conceptual Clarity and a Comprehensive Coategorization. In G. C. Leder, E. Pehkonen \& G. Törner (Eds.), Beliefs: A Hidden Variable in Mathematics Education? (pp. 13-38). Dordrecht, The Netherlands: Kluwer. https://doi.org/10.1007/o306-47958-3

Op’t Eynde, P., De Corte, E., \& Verschaffel, L. (2006). “Accepting Emotional Complexity": A SocioConstructivist Perspective on the Role of Emotions in the Mathematics Classroom.

Didactical Studies in Mathematics, 63(2), 193-207. https://doi.org/10.1007/s10649-0069034-4

Patrick, H., \& Pintrich, P. R. (2001). Conceptual change in teachers' intuitive conceptions of learning, motivation, and instruction: The role of motivational and epistemological beliefs. In B. Torff \& R. J. Sternberg (Eds.), Understanding and teaching the intuitive mind. Hillsdale, NJ: Lawrence Erlbaum (pp. 117-143).

Pehkonen, E. (1994). On Teachers' Beliefs and Changing Mathematics Teaching. Journal für Mathematik-Didaktik, 15(3), 177-209. https://doi.org/10.1007/BF03338807

Rokeach, M. (1975). Beliefs, attitudes and values: a theory of organization and change. San Francicsco, CA: Jossey-Bass.

Schreier, M. (2014). Varianten qualitativer Inhaltsanalyse: Ein Wegweiser im Dickicht der Begrifflichkeiten. Forum: Qualitative Social Research, 15(1). http://www.qualitativeresearch.net/index.php/fqs/rt/printerFriendly/2043/3635 
Schoenfeld, A. H. (1998). Toward a Theory of Teaching-in-Context. Issues in Education, 4(1), 194. https://doi.org/10.1016/S1080-9724(99)80076-7

Terhart, E. (2003). Constructivism and teaching: a new paradigm in general didactics? Journal of Curriculum Studies, 35(1), 25-44. https://doi.org/10.1080/00220270210163653

Vollstedt, M., Ufer, S., Heinze, A., \& Reiss, K. (2015). Forschungsgegenstände und Forschungsziele. In Bruder R. et al. (Eds.), Handbuch der Mathematikdidaktik (pp. 567590). Berlin, Germany: Springer Spektrum. https://doi.org/10.1007/978-3-642-35119-8 